\title{
G Protein Selectivity Is Regulated by Multiple Intracellular Regions of GPCRs
}

\author{
Stephen K.-F. Wong \\ Department of Neuroscience, Pfizer Global Research and Development, Groton, Conn., USA
}

\author{
Key Words \\ $\mathrm{G}$ protein coupled receptors $\cdot \mathrm{G}$ protein - Selectivity
}

\begin{abstract}
GTP-binding protein coupled receptors (GPCRs) bind to a vast diversity of extracellular ligands to regulate a wide variety of physiological responses. Upon binding of extracellular ligands, these seven-transmembrane-spanning receptor molecules couple to one or several subtypes of $\mathrm{G}$ protein which reside at the intracellular side of the plasma membrane to trigger intracellular signaling events. Amid the large structural diversity at the intracellular regions of GPCRs, there are only 18 different subtypes of $G$ protein belonging to four subfamilies. The question of how GPCRs select and activate a single or multiple $G$ protein subtype(s) has been the topic of intense investigations. This review will attempt to summarize the available data on the structural determinants in GPCRs that regulate the selectivity of G protein activation. The available data suggest that $G$ protein can be activated by structurally diverse cationic $\alpha$-helical structures with no obvious homology in primary sequence. The selectivity of receptor-G protein coupling is maintained by a combination of two functional domains at the intracellular region. One is the 'activation domain' which can activate multiple $G$ protein subtypes, while the other is the 'selectivity domain' which restricts the coupling to the desired signaling pathway(s). A slight change in the
\end{abstract}

conformation at these two functional domains can affect the fidelity of $\mathrm{G}$ protein selectivity. This hypothesis can account for the vast structural diversity of GPCRs which link a fascinating variety of extracellular inputs, yet couple to a limited number of intracellular signaling pathways.

Copyright $\odot 2003$ S. Karger AG, Basel

\section{G Protein Coupled Receptors}

GTP-binding protein coupled receptors ( $\mathrm{G}$ protein coupled receptors; GPCRs) represent the largest family of cell surface receptors known, with an estimated total of 1,000 members encoded in the human genome. These transmembrane molecules can be activated by a vast diversity of extracellular inputs such as biogenic amines, amino acids, odorants, lipids, ions, protease, nucleotides, peptides, large polypeptides, and even photons. A wide variety of physiological functions are regulated by GPCRs; examples are neurotransmission, visual perception, smell, taste, growth, secretion, metabolism, and immune and inflammatory responses. GPCRs, therefore, represent major targets for drug development, with chemical entities that are agonists, partial agonists, antagonists, or inverse agonists of GPCRs being pursued as therapeutics by the pharmaceutical industry. This is reflected in that an estimated $30 \%$ of the current pharmaceutical drugs are ligands for GPCRs [reviewed in 1]. Knowledge

\section{KARGER \\ Fax +4161306 1234 \\ E-Mail karger@karger.ch \\ www.karger.com

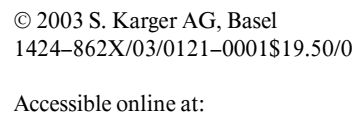

Stephen K.-F. Wong

Department of Neuroscience

Pfizer Global Research and Development, Eastern Point Road

Groton, CT 06340 (USA)

Tel. +1 860715 0065, Fax +1 860686 0013, E-Mail Stephen_Wong@Groton.Pfizer.com 
Table 1. G protein selectivity GPCRs

\begin{tabular}{|c|c|c|c|c|c|c|c|c|c|}
\hline Receptor & $\mathrm{Gq} / 11$ & $\mathrm{Gl} / \mathrm{o}$ & Gs & PubMed ID & Receptor & $\mathrm{Gq} / 11$ & $\mathrm{Gl} / \mathrm{o}$ & Gs & PubMed ID \\
\hline 5-Hydroxytryptamine $1 \mathrm{~A}$ receptor & & + & & 3138543 & D4 dopamine receptor & & + & & 1840645 \\
\hline 5-Hydroxytryptamine 1B receptor & & + & & 1351684 & D5 dopamine receptor & & & + & 1831904 \\
\hline 5-Hydroxytryptamine $1 \mathrm{D}$ receptor & & + & & 1565658 & Delta-type opioid receptor & & + & & 1335167 \\
\hline 5-Hydroxytryptamine $1 \mathrm{E}$ receptor & & + & & 1608964 & EDG-1 & & + & & 9488656 \\
\hline 5-Hydroxytryptamine $1 \mathrm{~F}$ receptor & & + & & 8384716 & EDG-2 lysophosphatidic acid receptor & & + & & 9070858 \\
\hline 5-Hydroxytryptamine $2 \mathrm{~A}$ receptor & + & & & 1765383 & EDG-3 lysosphingolipid receptor & + & + & & 9409733 \\
\hline 5-Hydroxytryptamine $2 \mathrm{~B}$ receptor & + & & & 8786115 & EDG-4 lysophosphatidic acid receptor & + & + & & 9525886 \\
\hline 5-Hydroxytryptamine $2 \mathrm{C}$ receptor & + & & & 1302605 & EDG-5 lysosphingolipid receptor & & + & & 10617617 \\
\hline 5-Hydroxytryptamine 4 receptor & & & + & 2849052 & EDG6 & + & & & 10679247 \\
\hline 5-Hydroxytryptamine $5 \mathrm{~A}$ receptor & & + & & 7988681 & EDG-7 lysophosphatidic acid & + & & & 10488122 \\
\hline 5-Hydroxytryptamine 6 receptor & & & + & 8522988 & Endothelin B receptor & + & + & & 1848367 \\
\hline 5-Hydroxytryptamine 7 receptor & & & + & 8397408 & Endothelin-1 receptor & + & & + & 1849646 \\
\hline Adenosine A1 receptor & & + & & 1662665 & Extracellular calcium-sensing receptor & + & & & 8255296 \\
\hline Adenosine $\mathrm{A} 2 \mathrm{~A}$ receptor & & & + & 1662665 & FMET-LEU-PHE receptor & & + & & 2176894 \\
\hline Adenosine A2B receptor & & & + & 11048721 & FMLP-related receptor 1 & & + & & 11160182 \\
\hline Adenosine $\mathrm{A} 3$ receptor & & + & & 1323836 & Follicle-stimulating hormone receptor & & + & + & 9139796 \\
\hline Alpha-1A adrenergic receptor & + & & & 8396931 & GABA-B1A receptor & & + & & 9872315 \\
\hline Alpha-1B adrenergic receptor & + & & & 1662393 & GABA-B2 receptor & & + & & 9872315 \\
\hline Alpha-1D adrenergic receptor & + & & & 1656955 & Galanin receptor type 1 & & + & & 7524088 \\
\hline Alpha-2A adrenergic receptor & + & + & + & 8662784 & Galanin receptor type 2 & + & + & & 9685625 \\
\hline Alpha-2B adrenergic receptor & & + & & 2164221 & Galanin receptor type 3 & & + & & 9722565 \\
\hline Alpha-2C-1 adrenergic receptor & & + & & 2842764 & Gastric inhibitory polypeptide receptor & & & + & 8243312 \\
\hline Apelin receptor & & + & & 9792798 & Gastrin-releasing peptide receptor & + & & & 1707129 \\
\hline B1 bradykinin receptor & + & & & 8063797 & Glucagon receptor & & & + & 8144028 \\
\hline B2 bradykinin receptor & + & & & 1314587 & Glucagon-like peptide-1 receptor & & & + & 1326760 \\
\hline Beta-1 adrenergic receptor & & & + & 2825170 & Glucagon-like peptide-2 receptor & & & + & 9990065 \\
\hline Beta-2 adrenergic receptor & & & + & 3041227 & Gonadotropin-releasing hormone receptor & + & & & 1333190 \\
\hline Beta-3 adrenergic receptor & & & + & 2570461 & Growth hormone secretagogue receptor type 1 & + & & & 8688086 \\
\hline Bombesin receptor subtype 3 & + & & & 8383682 & Growth hormone releasing hormone receptor & & & + & 7680413 \\
\hline C3A anaphylatoxin chemotactic receptor & + & + & & 8702752 & Histamine $\mathrm{H} 1$ receptor & + & & & 1722337 \\
\hline C5A anaphylatoxin chemotactic receptor & + & & & 8779720 & Histamine $\mathrm{H} 2$ receptor & & & + & 1703298 \\
\hline Calcitonin gene related peptide type 1 receptor & & & + & 8626685 & Histamine $\mathrm{H} 3$ receptor & & + & & 10347254 \\
\hline Calcitonin receptor & & & + & 1331173 & Histamine $\mathrm{H} 4$ receptor & & + & & 10973974 \\
\hline Cannabinoid receptor 1 & & + & & 2165569 & Kappa-type opioid receptor & & + & & 7624359 \\
\hline Cannabinoid receptor 2 & & + & & 7689702 & Leukotriene B4 receptor & + & + & & 9177352 \\
\hline CCR10 eskine & & + & & 10781587 & Lutropin-choriogonadotropic hormone receptor & + & + & + & 2502842 \\
\hline CCR2 & & + & & 8530354 & Melanocortin-1 receptor & & & + & 1516719 \\
\hline CCR3 & & + & & 8631813 & Melanocortin-2 receptor & & & + & 1325670 \\
\hline CCR4 & & + & & 9169480 & Melanocortin-3 receptor & & & + & 8463333 \\
\hline CCR5 & & + & & 8639485 & Melanocortin-4 receptor & & & + & 8392067 \\
\hline CCR6 & & + & & 9294137 & Melanocortin-5 receptor & & & + & 8185570 \\
\hline CCR7 & & + & & 9153236 & Melatonin receptor type $1 \mathrm{~A}$ & & + & & 7946354 \\
\hline CCR8 & & + & & 9207005 & Melatonin receptor type $1 \mathrm{~B}$ & & + & & 7568007 \\
\hline CCR9 & & + & & 10229797 & Metabotropic glutamate receptor 1 & + & & & 9076744 \\
\hline Chemokine CCR1 & & + & & 7679328 & Metabotropic glutamate receptor 2 & & + & & 1309649 \\
\hline Cholecystokinin type A receptor & + & & + & 8503909 & Metabotropic glutamate receptor 3 & & + & & 1309649 \\
\hline Cholecystokinin type B receptor & + & & & 1280419 & Metabotropic glutamate receptor 4 & & + & & 1309649 \\
\hline Corticotropin-releasing factor receptor 1 & & & + & 7692441 & Metabotropic glutamate receptor 5 & + & & & 7908515 \\
\hline Corticotropin-releasing factor receptor 2 & & & + & 8536644 & Metabotropic glutamate receptor 6 & & + & & 8389366 \\
\hline CX3CR 1 fractalkine receptor & & + & & 9390561 & Metabotropic glutamate receptor 7 & & + & & 8288585 \\
\hline CXCR1 & & + & & 1840701 & Metabotropic glutamate receptor 8 & & + & & 9473604 \\
\hline CXCR2 & & + & & 1891716 & Muscarinic acetylcholine receptor M1 & + & & & 3037705 \\
\hline CXCR3 & & + & & 9653165 & Muscarinic acetylcholine receptor M2 & & + & & 3443095 \\
\hline CXCR4 & & + & & 8629022 & Muscarinic acetylcholine receptor M3 & + & & & 11242080 \\
\hline CXCR5 & & + & & 11882900 & Muscarinic acetylcholine receptor M4 & & + & & 3037705 \\
\hline Cysteinyl leukotriene receptor CysLT2 & + & & & 10913337 & Muscarinic acetylcholine receptor M5 & + & & & 3037705 \\
\hline Cysteinyl leukotriene receptor CysLT1 & + & & & 10391245 & Mu-type opioid receptor & & + & & 8393525 \\
\hline D1 dopamine receptor & & & + & 2144334 & Neuromedin K receptor (NK-3) & + & & + & 1370820 \\
\hline D2 dopamine receptor & & + & & 2974511 & Neuromedin U receptor NMU1R & + & & & 10894543 \\
\hline D3 dopamine receptor & & + & & 1975644 & Neuromedin U receptor NMU2R & + & & & 10894543 \\
\hline
\end{tabular}

172 of the non-olfactory GPCRs with known $G$ protein coupling selectivity towards $G_{s}, G_{q / 11}$, and/or $G_{i / o}$. The references for the coupling can be found in http://www.ncbi.nlm.nih.gov/entrez/query.fcgi?db=PubMed using the PubMED ID listed in the table. 
Table 1 (continued)

\begin{tabular}{|c|c|c|c|c|}
\hline Receptor & $\mathrm{Gq} / 11$ & $\mathrm{Gl} / \mathrm{o}$ & Gs & PubMed ID \\
\hline Neuromedin-B receptor & + & & & 8026589 \\
\hline Neuropeptide Y receptor type 1 & + & + & & 1321422 \\
\hline Neuropeptide Y receptor type 2 & & + & & 7559383 \\
\hline Neuropeptide Y receptor type 4 & & + & & 7592911 \\
\hline Neuropeptide Y receptor type 5 & & + & & 8700207 \\
\hline Neurotensin receptor type 1 & + & & & 8381365 \\
\hline Neurotensin receptor type 2 & + & & & 8647296 \\
\hline Nociceptin receptor & & + & & 8137918 \\
\hline Orexin receptor type 1 & + & & & 9491897 \\
\hline Orexin receptor type 2 & + & & & 9491897 \\
\hline Oxytocin receptor & + & + & & 1313946 \\
\hline P2U purinoceptor 1 & + & & & 8159738 \\
\hline $\mathrm{P} 2 \mathrm{Y}$ purinoceptor 1 & + & & & 8579591 \\
\hline $\mathrm{P} 2 \mathrm{Y}$ purinoceptor 11 & + & & + & 9405388 \\
\hline P2Y purinoceptor 6 & + & & & 7592819 \\
\hline P2Y12 platelet ADP receptor & & + & & 11196645 \\
\hline Parathyroid hormone receptor & & & + & 7797535 \\
\hline Parathyroid hormone related peptide receptor & & & + & 1658941 \\
\hline Pituitary adenylate cyclase activating & & & & \\
\hline polypeptide type 1 receptor & + & & + & 8396727 \\
\hline Platelet-activating factor receptor & + & + & & 7876256 \\
\hline Protactin-releasing peptide receptor & + & & & 11030716 \\
\hline Prostacyclin receptor & & & + & 7512962 \\
\hline Prostaglandin D2 receptor & & & + & 7642548 \\
\hline Prostaglandin E2 receptor EP1 subtype & + & & & 8253813 \\
\hline Prostaglandin E2 receptor EP2 subtype & & & + & 7910583 \\
\hline Prostaglandin E2 receptor EP3 subtype & + & + & + & 11095474 \\
\hline Prostaglandin E2 receptor EP4 subtype & & & + & 8016385 \\
\hline Prostaglandin F2-alpha receptor & + & & & 8300593 \\
\hline Relaxin receptor LGR7 & & & + & 11809971 \\
\hline Relaxin receptor LGR8 & & & + & 11809971 \\
\hline Secretin receptor & & & + & 1646711 \\
\hline Somatostatin receptor type 1 & & + & & 1346068 \\
\hline Somatostatin receptor type 2 & & + & & 7622071 \\
\hline Somatostatin receptor type 3 & & + & & 1337145 \\
\hline Somatostatin receptor type 4 & & + & & 8483934 \\
\hline Somatostatin receptor type 5 & & + & & 8373420 \\
\hline Substance-K receptor (NK-2) & + & & + & 1370820 \\
\hline Substance-P receptor (NK-1) & + & & + & 1370820 \\
\hline Thrombin receptor & + & + & & 1672265 \\
\hline Thromboxane $\mathrm{A} 2$ receptor & + & & & 8300593 \\
\hline Thyrotropin receptor & + & + & + & 8552586 \\
\hline Thyrotropin-releasing hormone receptor & + & & & 2175902 \\
\hline Type 1 angiotensin II receptor & + & & & 2041570 \\
\hline Type 2 angiotensin II receptor & & + & & 7945336 \\
\hline Uridine nucleotide receptor & + & & & 8537335 \\
\hline Urotensin II receptor & + & & & 10499587 \\
\hline Vasoactive intestinal polypeptide receptor 1 & & & + & 1675791 \\
\hline Vasoactive intestinal polypeptide receptor 2 & & & + & 7733904 \\
\hline Vasopressin V1A receptor & + & & & 1560825 \\
\hline Vasopressin V1B receptor & + & & & 11091117 \\
\hline Vasopressin $\mathrm{V} 2$ receptor & & & + & 1534150 \\
\hline XCR 1 & & + & & 9632725 \\
\hline
\end{tabular}

about the mechanism of signaling of GPCRs will have a great impact in understanding the physiological processes and will enhance future drug discovery efforts.

Even before the identification of the cDNA of the first GPCR, biochemical and kinetic analysis had revealed a lot of information on the mechanisms of GPCR signaling [reviewed in 2]. An extracellular hormone agonist triggers the intracellular responses by binding to the ligand-binding site of the GPCR at the cell surface. The agonistbound GPCR then activates GTP-binding protein ( $\mathrm{G}$ protein) which consists of $\alpha \beta \gamma$ heterotrimer. In its basal, nonactivated state, the GDP-bound G protein $\alpha$ subunit is tightly associated with the $\beta \gamma$ complex. Upon activation, the $\alpha$ subunit exchanges the bound GDP with GTP at its guanine nucleotide binding site, with subsequent dissociation from the $\beta \gamma$ complex. Both the GTP-bound $\alpha$ subunit and the dissociated $\beta \gamma$ subunits regulate activities of intracellular effector molecules downstream.

At least 18 different subtypes of $\alpha$ subunits have been identified. They can be divided into four subfamilies: (1) the ' $G_{s}$ ' subfamily that stimulates adenylyl cyclase $\left(G_{s}\right.$ and $\left.\mathrm{G}_{\mathrm{olf}}\right)$; (2) the ' $\mathrm{G}_{\mathrm{i} / \mathrm{o}}$ ' subfamily that inhibits adenylyl cyclase and regulates ion channels $\left(G_{i 1}, G_{i 2}, G_{i 3}, G_{01}, G_{02}\right.$, $\mathrm{G}_{\mathrm{o} 3}, \mathrm{G}_{\mathrm{z}}, \mathrm{G}_{\mathrm{t} 1}, \mathrm{G}_{\mathrm{t} 2}$, and $\mathrm{G}_{\text {gust }}$ ); (3) the ' $\mathrm{G}_{\mathrm{q} / 11}$ ' subfamily that activates phospholipase $C \beta\left(\mathrm{G}_{\mathrm{q}}, \mathrm{G}_{11}, \mathrm{G}_{14}\right.$, and $\left.\mathrm{G}_{15 / 16}\right)$, and (4) the ' $\mathrm{G}_{12 / 13}$ ' subfamily that activates the $\mathrm{Na}^{+} / \mathrm{H}^{+}$ exchanger pathway $\left(G_{12}\right.$ and $\left.G_{13}\right)$. Depending on the subtype(s) of the $\mathrm{G}$ protein $\alpha$ subunit that a given GPCR interacts with, a single or a combination of effectors can be activated. In addition, the $\beta \gamma$ complex, which anchors the $\alpha$ subunit to the plasma membrane, had been shown to activate ion channels. Five subtypes of $\beta$ subunits and eleven subtypes of $\gamma$ subunits have been identified. A combination of different subtypes of $\alpha, \beta$, and $\gamma$ subunits provides a great diversity of intracellular signaling pathways that can be regulated by GPCRs.

The key event to trigger an intracellular response by GPCR is the coupling between GPCR and the $\alpha$ subunit of $\mathrm{G}$ protein. Activation of $\mathrm{G}$ protein by GPCR apparently does not require other molecules, as agonist-dependent activation was observed in phospholipid vesicles, where purified GPCR and G protein were reconstituted [reviewed in 3]. Understanding of the coupling specificity between GPCR and G protein thus resides at the G-protein- and receptor-coupling interface.

Table 1 summarizes the $\mathrm{G}$ protein coupling selectivity of 172 GPCRs, representing a major subset of all the presently known non-olfactory GPCRs. A greater part of these GPCRs couple to a single subtype of $G$ protein, with $\mathrm{G}_{\mathrm{i} / \mathrm{o}}$-coupled GPCRs being the majority (about $43 \%$ ), followed by $\mathrm{G}_{\mathrm{q} / 11}$-coupled receptor (33\%) and $\mathrm{G}_{\mathrm{s}}$-coupled receptor representing $25 \%$ of the total. Despite this wealth of information on GPCRs and their cognate $G$ protein partners, little is known about how GPCRs selectively couple to a single subtype of $G$ protein $\alpha$ subunit. This is 


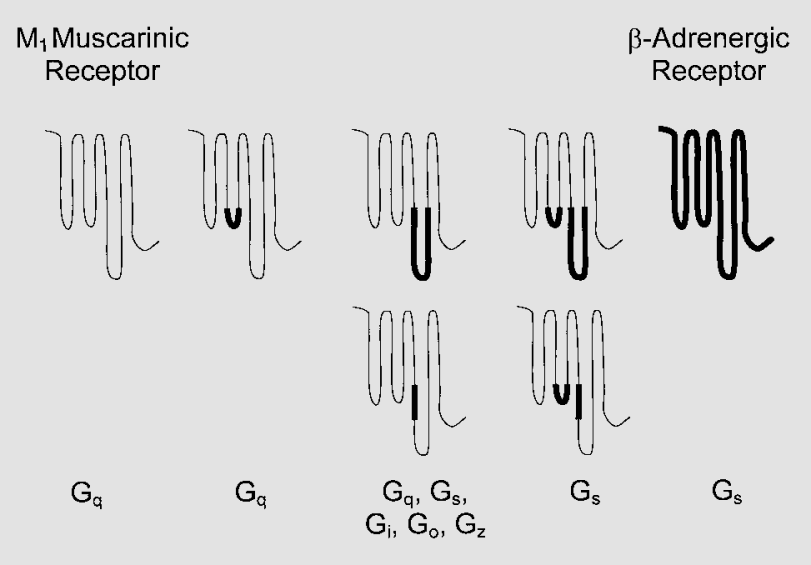

Fig. 1. G protein coupling specificity of chimeric muscarinic: $\beta$-adrenergic receptors. The intracellular loops (I2, I3, I3N, or their combination as indicated) of $\beta$-adrenergic receptor were substituted to the corresponding region of $\mathrm{M}_{1}$ muscarinic receptor as depicted. $\mathrm{G}$ protein specificities of the chimeric receptors are shown below. [Results are quoted from ref. 31.]

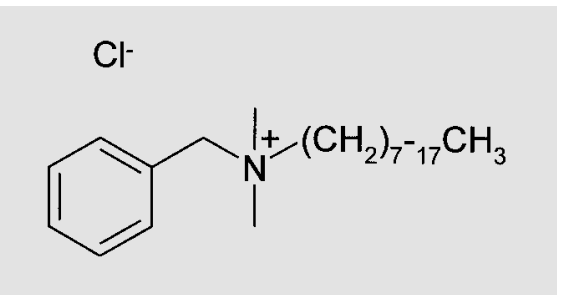

Fig. 2. Structure of benzalkonium chloride (alkyldimethylbenzylammonium chloride) which activates $\mathrm{G}_{0}[9]$.

particularly puzzling given that there are several thousand GPCRs of diverse primary structures [4], yet there are only four subfamilies of $G$ protein $\left(G_{i / o}, G_{s}, G_{q / 11}\right.$, and $\mathrm{G}_{12 / 13}$ ) to be activated by the receptors. No obvious sequence homology was observed even for GPCRs that couple to the same $G$ protein subtype, and no consensus motif predictive of $\mathrm{G}$ protein coupling has been identified [reviewed in 5]. In addition, a significant number of GPCRs have been shown to couple to multiple $G$ protein subtypes ( $11 \%$ of the GPCRs listed in table 1$)$. How do these GPCRs couple to multiple G proteins and how do the other GPCRs select for a single G protein subtype? These are fundamental questions without good answers thus far. This review will focus on these questions by summarizing data on the structural determinants required to activate $\mathrm{G}$ proteins and efforts to determine domains in GPCRs that regulate $G$ protein selectivity. A hypothesis that can potentially account for the available observations is proposed.

\section{Architecture of GPCRs}

GPCRs are seven-transmembrane-spanned molecules with the $\mathrm{N}$-terminus located on the extracellular side and the C-terminus on the intracellular side (fig. 1). Recent availability of the crystal structure of rhodopsin (a prototypic GPCR) [6] has confirmed the seven-transmembrane structure of GPCRs determined by hydrophobicity analysis on the primary sequences. The transmembrane spans are $\alpha$-helical segments interconnected by alternating extracellular and intracellular loops bundled together to form a heptahelical bundle-like structure [6]. Information of this general architecture of GPCR is important, as it suggests that there are significant intramolecular interactions amongst different extracellular as well as intracellular loops. Rather than interacting with a single region at the intracellular loop of GPCRs, G protein, which also has a globular structure [7], is predicted to interact simultaneously with multiple intracellular regions of GPCRs.

\section{What Does It Take to Activate G Protein?}

Activation of $\mathrm{G}$ protein by small peptides provides clues as to how $\mathrm{G}$ protein can be activated. The observation that purified $G_{0} \alpha$ subunits could be activated by the wasp venom peptide mastoparan, a 14 amino acid residue peptide, suggests that $G$ protein can be activated by short amphiphilic structures [8]. The activation highly resembles that of GPCRs. At a low concentration of $\mathrm{Mg}^{2+}$ $(>0.1 \mu M)$, mastoparan activates $\mathrm{G}$ protein by stimulating the guanine nucleotide exchange of $\mathrm{G}$ protein, and the activation can be blocked by pertussis toxin. The peptide also blocks the ability of $G_{0}$ to increase the affinity of muscarinic $\mathrm{M}_{2}$ receptor for its agonist, suggesting that mastoparan is acting at the receptor coupling site of $\mathrm{G}$ protein [9]. Structure-function relationship study using a variety of synthetic peptides with sequences distinct from mastoparan suggests that $G$ proteins can be activated by a variety of cationic and hydrophobic peptides with no obvious similarity in primary sequence [9]. G protein can be activated even by quaternary amines such as benzalkonium chloride (alkyldimethylbenzylammonium chloride; fig. 2). A common feature of these activators of $G_{0}$ 
appears to be amphiphilic $\alpha$-helical structure with a cationic residue on one side and a hydrophobic side chain on the other [10]. Similar conformation was found for $G_{s^{-}}$ activating peptide [11]. The apparent requirement of an amphiphilic $\alpha$-helical structure to activate $G_{q}$ was also demonstrated in a study using alanine insertion at the $\mathrm{N}$ terminal region of the third intracellular loop (I3N) of the $\mathrm{M}_{3}$ receptor [12]. Thus conformation and charge, rather than sequence homology, appear to be the major deciding factors for $G$ protein activation. This can explain the absence of obvious consensus sequence motifs in GPCRs which activate the same $G$ protein subunits.

The above data suggest that one mechanism of $\mathrm{G}$ protein activation by GPCR is: upon binding of agonist, the receptor changes its conformation to present an $\alpha$-helical amphiphilic cationic structure to the $\mathrm{G}$ proteins to stimulate guanine nucleotide exchange. This simple requirement for $G$ protein activation can account for the reported ligand-dependent activation of $G$ proteins by molecules which do not have a heptahelical structure: IGFII/mannose 6-phosphate receptor [13], amyloid precursor protein precursor protein [14], or atrial natriuretic peptide clearance receptor [15]. Non-ligand-mediated activation of $G$ protein by several molecules or their peptide fragments has also been reported in the literature: GAP43 [16], polycystin-1 [17], or presenilin-1 [18], although the physiological significance of these interactions in vivo remains to be determined.

The above results also raise cautions to interpret data using synthetic peptides derived from GPCR as an approach to locate the $G$ protein coupling regions of GPCRs. In these studies [reviewed in 19], synthetic peptides based on the primary sequences of GPCR were shown to activate $G$ proteins. While suggestive that the regions are the $\mathrm{G}$ protein activation domains in GPCRs, the activation can also be a mere coincidence, i.e., if the synthetic peptide can form cationic amphipathic helices, as in the cases of mastoparan and other cationic helical peptides. The presence of a large number of charged residues at the intracellular region of GPCRs can increase the chance for the receptor-derived peptides to activate $G$ proteins. This is illustrated by the activation of $\mathrm{G}_{\mathrm{s}}$ (but not $G_{i / o}$ ) by a synthetic peptide from the second intracellular loop of the $\alpha_{2}$-adrenergic receptor [20], a $G_{\mathrm{i} / 0}$-coupled GPCR which mainly couples to $G_{i / o}$ but not $G_{s}$. In addition, the conformation of the peptide fragment in the context of the heptahelical GPCR architecture can be distinct from that of the synthetic peptide. The observation that synthetic peptides can activate $G$ protein does not necessarily mean that the peptides will activate $G$ protein when inserted into the GPCR environment. Also, interpretation to conclude that a certain region of GPCR is the $G$ protein activation region from these studies needs to reconcile with the fact that in the unliganded state, GPCRs do not activate $G$ protein. Other ligand-mediated conformational change is necessary to induce the activation.

\section{Mutation Studies to Identify G Protein Coupling Regions of GPCRs}

Despite the lack of a crystal structure information on the GPCR:G protein complex, a wealth of information had been obtained on the regions of GPCRs that are involved in $\mathrm{G}$ protein coupling. A large number of studies using mutations at the putative intracellular regions suggested that the intracellular loops are key regions for $G$ protein coupling. A majority of these studies used deletion and domain swapping between GPCRs as strategies to identify the $\mathrm{G}$ protein coupling regions. The premise in these studies is that there is a single motif within GPCRs which is largely responsible for $\mathrm{G}$ protein activation and selectivity. Deletion of this domain would uncouple GPCR from $G$ protein. This assumption, while used successfully to identify functional domains for many single membrane-spanning biomolecules (e.g., the kinase superfamily), must be taken with caution for GPCRs. The juxtaposed seven-membrane-spanning architecture of GPCR suggests that the intracellular loops can interact with each other to form functional domain(s) to interact with $\mathrm{G}$ protein. Konig et al. [21] has previously shown that synthetic peptides from I2, I3, and the C-terminus of rhodopsin, a prototypic GPCR, can inhibit the interaction between rhodopsin and transducin, its cognate $G$ protein. Synergistic inhibition was observed when a combination of these peptides was used, suggesting that multiple intracellular loops of GPCR can interact with G protein. Deletion mutations that decrease $G$ protein coupling can result in a change in the overall folding at the intracellular regions, rather than from the lack of a region responsible for $\mathrm{G}$ protein coupling. It is with these uncertainties that make interpretations from deletion studies inconclusive.

Given the above caveats of deletion studies, deletions at the 2 nd and 3rd intracellular loops (I2, I3) or the $\mathrm{N}$ - and C-terminal regions of the 3rd intracellular loop (I3N, I3C) have resulted in GPCRs that no longer couple to G proteins while retaining their ligand-binding conformation $[22,23]$. These regions have been implicated to be 
Table 2. Chimeric GPCRs that have a change in G protein selectivity

\begin{tabular}{|c|c|c|c|c|c|c|c|c|}
\hline \multicolumn{2}{|c|}{ Acceptor receptor (R1) } & \multicolumn{3}{|c|}{ Donor receptor (R2) } & \multicolumn{3}{|c|}{$\begin{array}{l}\text { Chimeric receptor } \mathrm{R} 1-\mathrm{R} 2 \text { : } \\
\text { G protein selectivity }\end{array}$} & \multirow[t]{2}{*}{$\begin{array}{l}\text { Refer- } \\
\text { ence }\end{array}$} \\
\hline receptor & $\begin{array}{l}\text { G protein } \\
\text { selectivity }\end{array}$ & receptor & $\begin{array}{l}\text { regions } \\
\text { substituted }\end{array}$ & $\begin{array}{l}\text { G protein } \\
\text { selectivity }\end{array}$ & $\mathrm{R} 2$ & $\mathrm{R} 1$ & $\begin{array}{l}\text { other } \mathrm{G} \\
\text { proteins }\end{array}$ & \\
\hline$\alpha_{2} \mathrm{AR}$ & $\mathrm{G}_{\mathrm{i} / \mathrm{o}}$ & $\beta_{2} \mathrm{AR}$ & $\mathrm{I} 3$ & $\mathrm{G}_{\mathrm{s}}$ & + & ND & ND & 42 \\
\hline $\mathrm{mGluR}_{3}$ & $\mathrm{G}_{\mathrm{i} / \mathrm{o}}$ & $\mathrm{mGluR}_{1}$ & $\mathrm{I} 2+\mathrm{I} 3+\mathrm{C}$ & $\mathrm{G}_{\mathrm{q}}$ & + & ND & ND & 43 \\
\hline $\mathrm{D}_{3}$ & no coupling & $\mathrm{D}_{2}$ & $\mathrm{I} 3$ & $\mathrm{G}_{\mathrm{i} / \mathrm{o}}$ & + & ND & ND & 44 \\
\hline $\mathrm{D}_{2}$ & $\mathrm{G}_{\mathrm{i} / \mathrm{o}}$ & $\mathrm{M}_{1}$ & $\mathrm{I} 3$ & $\mathrm{G}_{\mathrm{q}}$ & + & ND & ND & 45 \\
\hline $\mathrm{D}_{2}$ & no coupling & thrombin & $\mathrm{I} 2$ & $\mathrm{G}_{\mathrm{q}}$ & + & ND & no $G_{\mathrm{s}}$ & 35 \\
\hline $\mathrm{M}_{2}$ & $\mathrm{G}_{\mathrm{i} / \mathrm{o}}$ & $\mathrm{M}_{3}$ & $\mathrm{I} 2$ & $\mathrm{G}_{\mathrm{q}}$ & + & ND & no $G_{s}$ & 36,46 \\
\hline $\mathrm{M}_{2}$ & $\mathrm{G}_{\mathrm{i} / \mathrm{o}}$ & $\mathrm{M}_{3}$ & $\mathrm{I} 3$ & $\mathrm{G}_{\mathrm{q}}$ & + & - & ND & 29 \\
\hline $\mathrm{M}_{3}$ & $\mathrm{G}_{\mathrm{q}}$ & $\mathrm{M}_{2}$ & $\mathrm{I} 3$ & $\mathrm{Gi} / \mathrm{o}$ & + & - & ND & 29 \\
\hline $\mathrm{M}_{2}$ & $\mathrm{G}_{\mathrm{i} / \mathrm{o}}$ & $\mathrm{M}_{3}$ & $\mathrm{I} 3 \mathrm{~N}$ & $\mathrm{G}_{\mathrm{q}}$ & + & + & ND & 29 \\
\hline A1A & $\mathrm{G}_{\mathrm{i} / \mathrm{o}}$ & $\mathrm{A} 2 \mathrm{~A}$ & $\mathrm{I} 3, \mathrm{I} 3 \mathrm{~N}$ & $\mathrm{G}_{\mathrm{s}}$ & + & + & ND & 47 \\
\hline$\beta_{2} \mathrm{AR}$ & $\mathrm{G}_{\mathrm{s}}$ & $\alpha_{2} \mathrm{AR}$ & $\mathrm{I} 3 \mathrm{~N}+\mathrm{I} 3 \mathrm{C}+\mathrm{C}$ & $\mathrm{Gi} / \mathrm{o}$ & + & + & ND & 48 \\
\hline$\beta_{2} \mathrm{AR}$ & $\mathrm{G}_{\mathrm{s}}$ & $\alpha_{1} \mathrm{AR}$ & $\mathrm{I} 3, \mathrm{I} 3 \mathrm{~N}$ & $\mathrm{G}_{\mathrm{q}}$ & + & + & ND & 49 \\
\hline$\beta_{2} \mathrm{AR}$ & $\mathrm{G}_{\mathrm{s}}$ & thrombin & $\mathrm{I} 2$ & $\mathrm{G}_{\mathrm{q}}$ & + & + & ND & 35 \\
\hline $\mathrm{PACAPR}_{2}$ & $\mathrm{G}_{\mathrm{s}}$ & PAFR & $\mathrm{I} 3$ & $\mathrm{G}_{\mathrm{q}}$ & + & + & ND & 50 \\
\hline $\mathrm{VP}_{2}$ & $\mathrm{G}_{\mathrm{s}}$ & $\mathrm{VP}_{1}$ & $\mathrm{I} 2$ & $\mathrm{G}_{\mathrm{q}}$ & + & + & no $G_{i / o}$ & 51 \\
\hline $\mathrm{VP}_{1}$ & $\mathrm{G}_{\mathrm{q}}$ & $\mathrm{VP}_{2}$ & $\mathrm{I} 3$ & $\mathrm{G}_{\mathrm{s}}$ & + & + & no $G_{i / o}$ & 51 \\
\hline $\mathrm{M}_{1}$ & $\mathrm{G}_{\mathrm{q}}$ & $\beta_{1} \mathrm{AR}$ & $\mathrm{I} 3, \mathrm{I} 3 \mathrm{~N}$ & $\mathrm{G}_{\mathrm{s}}$ & + & + & $\mathrm{G}_{\mathrm{i} / \mathrm{o}}, \mathrm{G}_{\mathrm{z}}$ & 30,31 \\
\hline $\mathrm{M}_{2}$ & $\mathrm{G}_{\mathrm{i} / \mathrm{o}}, \mathrm{G}_{\mathrm{z}}$ & $\beta_{1} \mathrm{AR}$ & $\mathrm{I} 3 \mathrm{~N}$ & $\mathrm{G}_{\mathrm{s}}$ & + & + & $\mathrm{G}_{\mathrm{q}}$ & 31 \\
\hline $\mathrm{M}_{1}$ & $\mathrm{G}_{\mathrm{q}}$ & $\beta_{1} \mathrm{AR}$ & $\mathrm{I} 2+\mathrm{I} 3 \mathrm{~N}, \mathrm{I} 2+\mathrm{I} 3$ & $\mathrm{G}_{\mathrm{s}}$ & + & - & no $G_{i / o}$, no $_{z}$ & 30,31 \\
\hline $\mathrm{M}_{2}$ & $\mathrm{G}_{\mathrm{i} / \mathrm{o}}, \mathrm{G}_{\mathrm{z}}$ & $\beta_{1} \mathrm{AR}$ & $\mathrm{I} 2+\mathrm{I} 3 \mathrm{~N}$ & $\mathrm{G}_{\mathrm{s}}$ & + & - & no $G_{\mathrm{q}}$, no $_{\mathrm{z}}$ & 31 \\
\hline
\end{tabular}

Chimeric receptors (R1-R2) were constructed with the indicated intracellular region of donor receptor (R2) substituted into the corresponding region of acceptor receptor (R1). I2 $=2$ nd intracellular loop; I3 = 3rd intracellular loop, I3N: N-terminal region of the 3rd intracellular loop; I3C = C-terminal region of the 3rd intracellular loop, $\mathrm{C}=$ C-terminal tail. All of the chimeric receptors presented have acquired the G protein selectivity of R2, while a majority of them have retained the coupling to the acceptor receptor or became functionally promiscuous. No coupling $=$ not detectable in the assay system used; ND = not determined.

involved in $\mathrm{G}$ protein coupling using chimeric receptors (see below). Deletion of a single amino acid at I2 of PACAP and $\mathrm{H}_{2}$ receptors resulted in constitutively active receptors $[24,25]$. While these results can indicate that the $\mathrm{I} 2$ loop in these receptors has a function to negatively regulate the activation of $G$ protein, a more conservative interpretation is that these mutations can introduce a conformational change in the receptor to enable constitutive coupling. Evidence to support this precaution is that constitutive $G$ protein activation was also observed with point mutations at regions believed not to be directly involved in $\mathrm{G}$ protein interaction. Examples of this include mutations at the 5th and 6th transmembrane spans of $\alpha$-adrenergic receptors [26], 1 st and 2 nd extracellular loops of the TSH receptor [27]. The same caution should also be taken to interpret other mutations in GPCRs that resulted in constitutive activation [reviewed in 28].

\section{Chimeric Receptors}

Perhaps a more convincing strategy to identify the $G$ protein coupling region is the use of chimeric receptors. In this approach, intracellular region(s) is(are) exchanged between GPCRs of different $G$ protein coupling specificity. Substituting these regions of the 'donor receptor' onto the corresponding region in another 'acceptor receptor' should change the specificity of coupling and redirect the chimeric receptor to 'abandon' the original G protein subtype and couple with a new $G$ protein $\alpha$ subunit. The assumption for this approach is that: First, $G$ protein specificity is a result of a gain of function by having a particular sequence motif rather than a loss of selectivity (or fidelity) as a result of the mutation. Based on this rationale, the experimental design of most of the published studies involves determining the functional response 
linked with the donor receptor-coupled $G$ protein. In many cases, the coupling to the $G$ protein of the acceptor receptor was not determined. Even fewer studies have looked into the possibility that the chimeric receptor will acquire the ability to couple a $G$ protein subtype of which neither parent receptors were linked to. The second assumption is that specificity of $\mathrm{G}$ protein coupling is mainly defined by one intracellular region. When a switch in specificity of $\mathrm{G}$ protein coupling is observed in the chimeric receptor, it is usually assumed that the other intracellular regions do not play a major role in defining the specificity in coupling. This assumption may be valid for GPCRs that are highly homologous in other intracellular regions, but may not apply to GPCRs the primary sequences of which are distinct from each other. Below are data that may challenge the above assumptions and caution the interpretation of the published data. The available data also give us insights into how GPCRs select $\mathrm{G}$ protein(s).

Table 2 shows data of some studies using the chimeric receptor strategy to identify regions in $\mathrm{G}$ protein coupling regions of GPCRs. When the 3rd intracellular loop (I3) was exchanged between GPCRs of similar receptor subfamilies, e.g., between $\alpha_{2}$ and $\beta_{2}$-adrenergic receptors, between dopamine $\mathrm{D}_{2}$ and $\mathrm{D}_{3}$ receptors, or between muscarinic $\mathrm{M}_{2}$ and $\mathrm{M}_{3}$ receptors, there appeared to be a switch in specificity of $G$ protein coupling. These chimeric receptors acquired the $G$ protein specificity of the donor receptor without retaining the $\mathrm{G}$ protein coupling of the acceptor receptor [29]. These results indicate the importance of I3 in G protein selectivity within closely structurally related GPCRs.

For most other chimeric receptors, however, exchanging either the 2 nd and 3rd intracellular loops or its $\mathrm{N}$ terminal region does not appear to be sufficient to exchange the specificity of $G$ protein coupling. Most of these chimeric receptors acquired the $G$ protein specificity of the donor GPCR, but yet retained the ability to couple to the acceptor receptor $G$ protein (table 2). In the case of $\mathrm{D}_{2}$ :thrombin and $\mathrm{D}_{2}: \mathrm{M}_{1}$ chimeric receptors, the ability of coupling to $\mathrm{G}_{\mathrm{i} / \mathrm{o}}$ (acceptor $\mathrm{G}$ protein) was not determined. It is possible that the $\mathrm{D}_{2}$ chimera also retains coupling to $\mathrm{G}_{\mathrm{i} / \mathrm{o}}$ as well. The above results suggest that coupling of chimeric receptor to one $\mathrm{G}$ protein subtype does not necessarily result in the loss of coupling to other $\mathrm{G}$ protein(s). It appears, therefore, that GPCRs are free to interact with multiple $\mathrm{G}$ protein subtypes.

Multiple $\mathrm{G}$ protein coupling of chimeric GPCRs also raises the question on the structural basis for how GPCR selects multiple $\mathrm{G}$ protein subtypes. There are several pos- sibilities to account for the coupling: first, different regions of GPCR interact with different $G$ protein subtypes, and the mutation did not prevent the interaction with the acceptor receptor $G$ protein. Second, rather than a 'gain of function' to acquire the coupling of $G$ protein, the mutation has resulted in a 'loss of function' and lost its ability to select a single $G$ protein subtype. That is, the chimeric GPCR has lost its fidelity of activating only a single $G$ protein subtype and couple nondiscriminately to more than one $G$ protein subtype. This in turn would suggest that there are other determinants in the native donor receptor to steer the native receptor away from other $G$ protein subtypes that are not desired.

\section{Promiscuous GPCRs}

The studies using chimeric muscarinic $M_{1}$ and $M_{2}$ receptors with various intracellular loops of $\beta$-adrenergic receptor $(\beta \mathrm{AR})$ perhaps provide an initial clue to distinguish the above possibilities. In the initial study [30] I3 or its N-terminal region of $\beta \mathrm{AR}$ was substituted into the corresponding regions of muscarinic $M_{1}$ receptor (M1- $\beta \mathrm{I} 3$ and M1- $\beta \mathrm{I} 3 \mathrm{~N})$. Similar to many other chimeric GPCRs presented in table 2, these chimeric receptors activate both $G_{\mathrm{s}}$ (donor receptor $G$ protein) and $G_{q}$ (acceptor receptor $G$ protein) in response to muscarinic agonists. As discussed above, the dual coupling of the chimeric muscarinic: $\beta$-adrenergic receptors can either be due to other region(s) in $M_{1}$ which can activate $G_{q}$ after its $I 3$ was replaced or due to the fact that the mutation has caused the chimeric receptor to lose its ability to distinguish $\mathrm{G}_{\mathrm{s}}$, $\mathrm{G}_{\mathrm{q}}$, and perhaps other $\mathrm{G}$ protein subtypes as well. To discern between these possibilities, purified M1- $\beta \mathrm{I} 3$ was reconstituted with purified $G_{s}, G_{i}, G_{q}, G_{0}$, or $G_{z}$ in phospholipid vesicles to determine the receptor: $G$ protein selectivity [31]. In the case of $G_{i}, G_{0}, G_{z}$, very little functional coupling was observed with either parent receptor $\mathrm{M}_{1}$ or $\beta \mathrm{AR}$. However the M1- $\beta \mathrm{I} 3$ was observed to couple to $G_{i}, G_{0}$, and $G_{z}$, in addition to $G_{s}$ and $G_{q}$ (fig. 1 ). The result strongly suggests that the ability of M1- $\beta$ I 3 to couple to $G_{\mathrm{q}}$ and $\mathrm{G}_{\mathrm{s}}$ is due to its loss of ability to discriminate between different $\mathrm{G}$ protein subtypes, i.e., it has become functionally promiscuous. Similar promiscuity in coupling was also observed in chimeric $\mathrm{M}_{2}$ with $\mathrm{I} 3 \mathrm{~N}$ of $\beta \mathrm{AR}$ (M2-ßI3N) [31].

Besides the functional promiscuous GPCRs created artificially and described above, naturally occurring functionally promiscuous GPCRs are known. For example, the TSH receptor can couple to all known G protein sub- 
Table 3. GPCR splice variants with different G protein selectivity

\begin{tabular}{llll}
\hline Receptor & Splice location & $\begin{array}{l}\mathrm{G} \text { protein } \\
\text { selectivity }\end{array}$ & $\begin{array}{l}\text { Refer- } \\
\text { ences }\end{array}$ \\
\hline Prostaglandin $\mathrm{EP}_{3}$-A & C-terminus & $\mathrm{G}_{\mathrm{i} / \mathrm{o}}$ & 38 \\
Prostaglandin $\mathrm{EP}_{3}$-B & C-terminus & $\mathrm{G}_{\mathrm{s}}$ & 38 \\
Prostaglandin $\mathrm{EP}_{3}-\mathrm{C}$ & C-terminus & $\mathrm{G}_{\mathrm{s}}$ & 38 \\
Prostaglandin $\mathrm{EP}_{3}$-D & C-terminus & $\mathrm{G}_{\mathrm{i} / \mathrm{o}}, \mathrm{G}_{\mathrm{q}}$ & 38 \\
Prostaglandin $\mathrm{EP}_{3}$ & C-terminal & constitutively & \\
& truncation & activated $\mathrm{G}_{\mathrm{i} / \mathrm{o}}$ & 33 \\
PACAP-R & I3C & $\mathrm{G}_{\mathrm{q}}, \mathrm{G}_{\mathrm{s}}$ & 52 \\
PACAP-R-hip & I3C & $\mathrm{G}_{\mathrm{q}}$ & 52 \\
PACAP-R-hop1 & I3C & $\mathrm{G}_{\mathrm{q}}, \mathrm{G}_{\mathrm{s}}$ & 52 \\
PACAP-R-hop2 & I3C & $\mathrm{G}_{\mathrm{q}}, \mathrm{G}_{\mathrm{s}}$ & 52 \\
PACAP-R-hip-hop1 & I3C & $\mathrm{G}_{\mathrm{q}}, \mathrm{G}_{\mathrm{s}}$ & 52 \\
\hline
\end{tabular}

Naturally occurring splice variants prostaglandin $\mathrm{EP}_{3}$ and PACAP receptors have different $G$ protein selectivity. The location within the receptor where splice event occurs and respective $G$ protein selectivity are presented.

families: $G_{s}, G_{i / 0}, G_{q}$, and $G_{12 / 13}$ [32]. Splice variants at the $\mathrm{C}$-terminal region of $\mathrm{I} 3$ of the $\mathrm{LH} / \mathrm{GH}$ receptor couple to a combination of $\mathrm{G}_{\mathrm{s}}, \mathrm{G}_{\mathrm{q} / 11}$, and $\mathrm{G}_{\mathrm{i} / \mathrm{o}}$ (table 3). Another interesting example is the splice variants at the C-terminal tail of prostaglandin EP3 receptor which can couple one or several of all subfamilies of $\mathrm{G}$ protein. The C-terminal region is unlikely to be directly involved in the activation of $\mathrm{G}$ protein, as truncation of this region resulted in constitutively active receptor [33] (table 3). These results suggest that the $\mathrm{C}$-terminal tail of the receptor constraints the receptor from activating and regulates the selectivity towards G protein. The ability of other GPCRs listed in table 1 to couple to multiple $G$ protein subtypes can thus be a natural phenomenon, and this may be an inherent property of many GPCRs.

\section{G Protein Selectivity Domains}

The fidelity of single $\mathrm{G}$ protein coupling for a majority of GPCRs (table 1) suggests the presence of an intracellular region to restrict the GPCRs from interacting with more than one $\mathrm{G}$ protein. This was demonstrated in the M1- $\beta \mathrm{I} 3, \mathrm{M} 1-\beta \mathrm{I} 3 \mathrm{~N}$, or M2- $\beta \mathrm{I} 3 \mathrm{~N}$ chimeric receptors where an additional substitution of I 2 from $\beta$ AR $(\beta I 2)$ apparently restricts the functionally promiscuous chimeric muscarinic: $\beta A R$ receptors to couple to $G_{s}$ only $[30,31]$ (fig. 1). The resulting chimeric receptors (M1- $\beta$ I2- $\beta \mathrm{I} 3$; M1- $\beta$ I2- $\beta I 3 N$; M2- $\beta$ I2- $\beta \mathrm{I} 3 \mathrm{~N}$ ) thus have the $\mathrm{G}$ protein selectivity of $\beta A R$ with the ligand-binding specificity of muscarinic receptor. I2 of the $\beta A R$, therefore, appears to have an uncoupling function towards $G$ proteins which are not $G_{s}$. This is supported by a decrease of potency of $G_{q}$ coupling in M1:ßI2 chimeric receptor [30]. The role of I2 as a selectivity domain towards $\mathrm{G}_{\mathrm{s}}$ was also demonstrated in other GPCRs. In the context of $\alpha_{2}$-adrenergic receptor that couples to both $\mathrm{G}_{\mathrm{s}}$ (in the presence of pertussis toxin) and $\mathrm{G}_{\mathrm{i} / \mathrm{o}}$ (in the presence of cholera toxin) [34] (table 2), substitution of $I 2$ from $\beta_{2} A R$ appears to disrupt $G_{i / o}$ coupling while maintaining the coupling to $\mathrm{G}_{\mathrm{s}}$. It is important to point out that, at least in the context of $\mathrm{M}_{1}$ and $\mathrm{M}_{2}$, the substitution of $\beta$ I2 (M1- $\beta$ I2 and M2- $\beta$ I2) was not sufficient to uncouple from the acceptor receptor $G$ protein $\left(\mathrm{G}_{\mathrm{q}}\right.$ and $\mathrm{G}_{\mathrm{i} / \mathrm{o}}$, respectively) [30,31]. The fidelity of coupling to a single $G$ protein coupling appears to require a combination of distinct intracellular regions (fig. 1). The specificity of G protein coupling of these GPCR mutants was demonstrated in an in vitro reconstituted system using purified receptor and $G$ protein, further indicating that the structural determinants in GPCR have all the necessary components to define the selectivity of $\mathrm{G}$ protein coupling.

The above hypothesis would also predict that disruption of $\mathrm{I} 2$ in $\beta A R$ should lead to a loss in fidelity of $G$ protein coupling. This is indeed what was observed. When $\mathrm{I} 2$ of the thrombin was substituted to $\beta A R$, the chimeric receptor lost its fidelity in $G$ protein coupling and activated both $\mathrm{G}_{\mathrm{s}}$ and $\mathrm{G}_{\mathrm{q}}$ [35] (table 2). Not all substitution to I2 in $\beta A R$ resulted in the loss of fidelity, as substituting I 2 of $\mathrm{D}_{2}$ into $\beta \mathrm{AR}$ did not affect the selectivity of $\beta A R$ [35] (table 2). The similarity in sequence in I2 between $\beta A R$ and $D_{2}$ is a likely explanation, as the tyrosine residue in the DRY motif common to all aminergic GPCR is absent in I 2 of thrombin receptor, while $\mathrm{I} 2$ of $\mathrm{D}_{2}$ retains this conserved DRY motif.

Another outcome from the above hypothesis is that mutations in GPCRs that disrupt the interaction between I 2 and I3 will also result in a loss of fidelity to couple to a single $\mathrm{G}$ protein subtype. As shown in table 2, a majority of the receptors having domain swapping mutations at I2, $\mathrm{I} 3$, or I3N described in table 2 couple to more than one $\mathrm{G}$ protein subtype. Shorter mutations at $\mathrm{I} 2$ of $\mathrm{M}_{2}$ or $\mathrm{I} 3 \mathrm{~N}$ of $M_{1}$ (table 4) led to a change in specificity in coupling. The coupling to the acceptor receptor $\mathrm{G}$ protein in several of these studies was not determined; it is possible that these receptors also couple to multiple $G$ protein subtypes. It will also be of interest to determine the coupling to the $G$ protein subtype which does not couple to either parent 
Table 4. Other mutations of GPCRs that change G protein selectivity

\begin{tabular}{|c|c|c|c|c|}
\hline Receptor & $\begin{array}{l}\text { G protein } \\
\text { selectivity }\end{array}$ & Mutation & $\begin{array}{l}\mathrm{G} \text { protein selectivity } \\
\text { of receptor mutants }\end{array}$ & References \\
\hline $\mathrm{M}_{2}$ & $\mathrm{G}_{\mathrm{i} / \mathrm{o}}$ & 4 AA mutation at I2 & $\mathrm{G}_{\mathrm{q}}$, coupling to $\mathrm{G}_{\mathrm{i} / \mathrm{o}}$ not determined & 36 \\
\hline $\mathrm{M}_{1}$ & $\mathrm{G}_{\mathrm{q}}$ & 4 AA mutation at $\mathrm{I} 3 \mathrm{~N}$ & $\mathrm{G}_{\mathrm{s}}, \mathrm{G}_{\mathrm{q}}$ & $\begin{array}{l}\text { Wong and Ross } \\
\text { unpublished }\end{array}$ \\
\hline LH-CG & $\mathrm{G}_{\mathrm{s}}, \mathrm{G}_{\mathrm{q}}$ & point mutation at extracellular loop 3 & $\mathrm{G}_{\mathrm{q}}$, disruption of $\mathrm{G}_{\mathrm{s}}$ coupling & 53 \\
\hline$\alpha_{2} \mathrm{AR}$ & $\mathrm{G}_{\mathrm{i}}, \mathrm{G}_{\mathrm{k}}$ & D79 N (at 2nd span) & $\mathrm{G}_{\mathrm{i}}$, disruption of $\mathrm{G}_{\mathrm{k}}$ coupling & 54 \\
\hline$\alpha_{2} \mathrm{AR}$ & $\mathrm{G}_{\mathrm{s}}, \mathrm{G}_{\mathrm{i} / \mathrm{o}}$ & substitution of I2 of $\beta A R$ & $\mathrm{G}_{\mathrm{s}}$, disruption of $\mathrm{G}_{\mathrm{i} / \mathrm{o}}$ coupling & 34 \\
\hline$\alpha_{2} \mathrm{AR}$ & $\mathrm{G}_{\mathrm{s}}, \mathrm{G}_{\mathrm{i} / \mathrm{o}}$ & substitution of $\mathrm{I} 3 \mathrm{~N}, \mathrm{I} 3 \mathrm{C}$ of $5 \mathrm{HT}_{1 \mathrm{~A}}$ & $\mathrm{G}_{\mathrm{i} / \mathrm{o}}$, disruption of $\mathrm{G}_{\mathrm{s}}$ coupling & 34 \\
\hline $\mathrm{Mel}_{1 \mathrm{c}}$ & $\mathrm{G}_{\mathrm{i} / \mathrm{o}}$ & C-terminal truncation & $\mathrm{G}_{\mathrm{i} / \mathrm{o}}, \mathrm{G}_{16}$ & 37 \\
\hline $\mathrm{MT}_{1}, \mathrm{MT}_{2}$ & $\mathrm{G}_{\mathrm{i} / \mathrm{o}}, \mathrm{G}_{16}$ & insertion of $\mathrm{C}$ terminal tail of $\mathrm{Mel}_{1 \mathrm{c}}$ & $\mathrm{G}_{\mathrm{i} / \mathrm{o}}$ & 37 \\
\hline $\mathrm{Mel}_{1 \mathrm{c}}$ & $\mathrm{G}_{\mathrm{i} / \mathrm{o}}$ & substitution with C-terminal of $\mathrm{MT}_{1}, \mathrm{MT}_{2}$ & $\mathrm{G}_{\mathrm{i} / \mathrm{o}}, \mathrm{G}_{16}$ & 37 \\
\hline
\end{tabular}

$\mathrm{G}_{\mathrm{k}}=\mathrm{G}$ protein that mediates $\mathrm{K}^{+}$channel activation.

receptors to determine the full $\mathrm{G}$ protein selectivity profile of these receptors. For those GPCRs that couple to more than one $G$ protein subtype, additional substitution of other intracellular regions from the donor receptor would determine if these regions are involved in regulating $\mathrm{G}$ protein selectivity.

Not all single-domain substitutions led to a loss of fidelity in $\mathrm{G}$ protein coupling. Domain swapping of I3 between $\mathrm{M}_{2}$ and $\mathrm{M}_{3}$ appears to exchange the specificity in $\mathrm{G}$ protein coupling [29]. The high degree of sequence identity between $\mathrm{M}_{2}$ and $\mathrm{M}_{3}$ in $\mathrm{I} 2$ can account for the absence of coupling to more than one $\mathrm{G}$ protein subtype. However, when $\mathrm{I} 2$ of $\mathrm{M}_{3}$ was substituted to $\mathrm{M}_{2}$ receptor, the chimeric $M_{2}$ receptor coupled to $G_{q}$ [36], indicating either $\mathrm{I} 2$ of $\mathrm{M}_{3}$ directs coupling to $\mathrm{G}_{\mathrm{q}}$ or that the mutation disrupts the ability of the $\mathrm{M}_{2}$ chimeric receptor to select between $G_{q}$ and $G_{i}$. Given the fact that a four amino acid mutation at $\mathrm{I} 2$ of $\mathrm{M}_{2}$ enabled the $\mathrm{M}_{2}$ receptor to couple to $\mathrm{G}_{\mathrm{q}}$ [36], the second possibility is favored. Mutations at I2 of $\mathrm{M}_{2}$ do not always lead to a change in $G$ protein specificity, chimeric $\mathrm{M}_{2}$ having $\mathrm{I} 2$ of $\beta A R$ has similar $\mathrm{G}$ protein specificity as the native $\mathrm{M}_{2}$ receptor [30]. Thus, the selectivity $\mathrm{G}$ protein coupling in the chimeric receptor is highly dependent on the context of the acceptor receptor and the sequence from the donor receptor substituted.

Besides $\mathrm{I} 2$ and $\mathrm{I} 3$, a $\mathrm{G}$ protein selectivity region was also demonstrated at the C-terminal region of GPCRs. Truncation of the $\mathrm{C}$-terminal tail of $\mathrm{Mel}_{1 \mathrm{c}}$ receptor, which couples to $G_{i / o}$ only, enabled the receptor to couple to $G_{i / o}$ and $\mathrm{G}_{16}$ [37]. Crafting this C-terminal region of $\mathrm{Mel}_{1 \mathrm{c}}$ to the C-terminus of $\mathrm{MT}_{1}$ or $\mathrm{MT}_{2}$, which couples to both $\mathrm{G}_{\mathrm{i} / \mathrm{o}}$ and $\mathrm{G}_{16}$, disrupted the coupling to $\mathrm{G}_{16}$ but not $\mathrm{G}_{\mathrm{i} / \mathrm{o}}$ (ta- ble 4). The C-terminal region of $\mathrm{Mel}_{1 \mathrm{c}}$ thus appears to negatively regulate the coupling to $\mathrm{G}_{16}$ but not $\mathrm{G}_{\mathrm{i} / \mathrm{o}}$. The ability of the $\mathrm{C}$-terminal tail to regulate $\mathrm{G}$ protein selectivity had also been demonstrated in the prostaglandin $\mathrm{EP}_{3}$ receptors [38].

\section{Conformation of GPCRs Defines G Protein Selectivity}

Surprisingly little alteration in amino acid sequence for GPCR is needed for a change in G protein selectivity. Point mutations of $\mathrm{LH} / \mathrm{RH}$ receptor (2nd extracellular loop) and $\alpha_{2}$-adrenergic receptor (2nd membrane span) uncouple one $\mathrm{G}$ protein subtype while retaining the coupling to another subtype (table 4). These mutations are remote from the intracellular region of GPCRs and support the idea that the change in $G$ protein selectivity in these mutant GPCRs results from a change of conformation in the intracellular domain. This hypothesis can also account for the change of $G$ protein specificity upon changes of four amino acid residues at $\mathrm{I} 3 \mathrm{~N}$ and $\mathrm{I} 2$ of $\mathrm{M}_{1}$ and $\mathrm{M}_{2}$ [36] (table 4). These results argue against the presence of a 'consensus' $G$ protein coupling motif to direct $G$ protein selectivity. Rather, the change in $G$ protein selectivity in these receptor point mutants more likely resulted from a loss in fidelity of $G$ protein coupling due to a change in conformation at the intracellular region.

The above hypothesis is supported by the presence of naturally occurring promiscuous $G$ proteins such as $G_{15}$ and $G_{16}$ [reviewed in 39]. Each of these two $G$ protein subtypes couples to a variety of $\mathrm{G}_{\mathrm{s}^{-}}, \mathrm{G}_{\mathrm{i} / \mathrm{o}^{-}}$, and $\mathrm{G}_{\mathrm{q}}$-linked 
GPCRs and activates phospholipase $C \beta$. This argues that conformation of the agonist-bound GPCR to activate $G$ protein is very similar. A subtle change in conformation of GPCR can result in a change in G protein selectivity. This can account for the difference in $G$ protein selectivity of different splice variants of $\mathrm{EP}_{3}$ receptor with mutations at the C-terminal tail [38] (table 3). Different C-terminal splice variants of the $\mathrm{EP}_{3}$ receptor can modulate the conformation of the other intracellular loops to influence the selectivity of $\mathrm{G}$ protein coupling. Similar explanation can be extended to the splice variants at the C-terminal region of $\mathrm{I} 3$ of the PACAP receptor that has different selectivity in $\mathrm{G}$ protein coupling (table 3 ).

The concept of overall conformation, rather than a stretch of the sequence motif, in intracellular regions of GPCRs to define $G$ protein selectivity can account for the lack of consensus $\mathrm{G}$ protein coupling sequences amongst all the GPCRs identified thus far. This concept will be important in our understanding of the structural basis of GPCR function. In the light of the recent identification of GPCR heterodimers [40, 41], it will be interesting to see whether heterodimerization occurs for GPCRs which couple to different $G$ protein subfamilies and, if so, whether heterodimerization affects $\mathrm{G}$ protein selectivity.

\section{A New View on the Structural Basis for G Protein Selectivity of GPCRs}

This review provides a new view on the structural basis for $\mathrm{G}$ protein selectivity of GPCRs. G protein selectivity is defined by the conformation at the intracellular region of GPCRs. This conformation is regulated by the interaction between several intracellular regions. Rather than one receptor region directing the specificity of $G$ protein coupling, the selectivity is a result of a combination of one 'activation domain' which can activate multiple $G$ protein subtypes and another 'selectivity domain' to restrict the promiscuous coupling. This hypothesis is supported by: (1) the presence of naturally occurring GPCRs which can couple to multiple G protein subtypes; (2) the activation of $G$ protein by small cationic helical structure; (3) no consensus $\mathrm{G}$ protein coupling motif amongst GPCRs; (4) naturally occurring splice variants that restrict or alter the selectivity of $\mathrm{G}$ protein coupling; (5) change of $\mathrm{G}$ protein selectivity by point mutations at nonintracellular domain and intracellular loops; (6) loss of fidelity of coupling to a single $G$ protein subtype in many GPCR mutants, and (7) promiscuous coupling of chimeric muscarinic: $\beta A R$, the fidelity of selectivity of which towards
$\mathrm{G}_{\mathrm{s}}$ can be rescued by an additional substitution of $\mathrm{I} 2$ of $\beta A R$.

The structural basis for $\mathrm{G}$ protein selectivity proposed above can also explain the purpose of the heptahelical structure and the sequence diversity of GPCR. The sevenmembrane spans form the ligand-binding pocket and provide the necessary architecture to the three intracellular loops and the C-terminal tail to form a three-dimensional 'pocket' to regulate agonist-mediated $\mathrm{G}$ protein activation and selectivity amongst $G$ protein subtypes. This region is designed in fascinating sequence diversity amongst GPCRs, yet having similar conformation and mode of action to couple to limited subtypes of $\mathrm{G}$ protein. This provides a platform for the GPCR superfamily to bind an amazing variety of extracellular receptor ligands and allows it to couple to a few intracellular signaling pathways. A slight change of conformation can alter efficacy and selectivity of $\mathrm{G}$ protein activation, and this enables the receptor- $G$ protein interaction to be fine-tuned by different extracellular ligands as well as by the intracellular environment. Deeper understanding of how GPCR interacts with $G$ protein awaits the crystal structure of the GPCR:G protein complex, more mutation analysis to validate the proposed model, and the development of bioinformatic algorithms to predict the three-dimensional structure at the receptor-G protein interface.

\section{Acknowledgements}

The author wishes to thank Elliott Ross, Enoch Huang, and Alka Shrikhande for helpful comments on the manuscript.
10

Neurosignals 2003;12:1-12
Wong 


\section{References}

1 Hopkins AL, Groom CR: The druggable genome. Nat Rev Drug Discov 2002;1:727-730.

2 Ross EM, Gilman AG: Biochemical properties of hormone-sensitive adenylate cyclase. Annu Rev Biochem 1980;49:533-564.

3 Cerione RA, Ross EM: Reconstitution of receptors and $G$ proteins in phospholipid vesicles. Methods Enzymol 1991;195:329-342.

4 Probst WC, Snyder LA, Schuster DI, Brosius J, Sealfon SC: Sequence alignment of the G-protein-coupled receptor superfamily. DNA Cell Biol 1992;11:1-20.

5 Moller S, Vilo J, Croning MD: Prediction of the coupling specificity of $G$ protein coupled receptors to their $G$ proteins. Bioinformatics 2001;17(suppl 1):174-181.

6 Palczewski K, Kumasaka T, Hori T, Behnke CA, Motoshima H, Fox BA, Le Trong I, Teller DC, Okada T, Stenkamp RE, Yamamoto M, Miyano M: Crystal structure of rhodopsin: A G protein-coupled receptor. Science 2000;289: 739-745.

7 Mixon MB, Lee E, Coleman DE, Berghuis AM, Gilman AG, Sprang SR: Tertiary and quaternary structural changes in Gi alpha 1 induced by GTP hydrolysis. Science 1995;270:954960

8 Higashijima T, Uzu S, Nakajima T, Ross EM: Mastoparan, a peptide toxin from wasp venom, mimics receptors by activating GTP-binding regulatory proteins (G proteins). J Biol Chem 1988;263:6491-6494.

9 Higashijima T, Burnier J, Ross EM: Regulation of $G_{i}$ and $G_{o}$ by mastoparan, related amphiphilic peptides, and hydrophobic amines; Mechanism and structural determinants of activity. J Biol Chem 1990;265:14176-14186.

10 Wakamatsu K, Okada A, Miyazawa T, Ohya M, Higashijima T: Membrane-bound conformation of mastoparan-X, a G-protein-activating peptide. Biochemistry 1992;31:5654 5660 .

11 Sukumar M, Ross EM, Higashijima T: $\mathrm{A} \mathrm{G}_{\mathrm{s}^{-}}$ selective analog of the receptor-mimetic peptide mastoparan binds to $\mathrm{G}_{\mathrm{s}}$ alpha in a kinked helical conformation. Biochemistry 1997;36: 3632-3639.

12 Blüml K, Mutschler E, Wess J: Insertion mutagenesis as a tool to predict the secondary structure of a muscarinic receptor domain determining specificity of G-protein coupling. Proc Natl Acad Sci USA 1994;91:7980-7984.

13 Okamoto T, Katada T, Murayama Y, Ui M, Ogata E, Nishimoto I: A simple structure encodes $\mathrm{G}$ protein-activating function of the IGFII/mannose 6-phosphate receptor. Cell 1990; 62:709-717.

14 Okamoto T, Takeda S, Murayama Y, Ogata E, Nishimoto I: Ligand-dependent G protein coupling function of amyloid transmembrane precursor. J Biol Chem 1995;270:4205-4208.

15 Murthy KS, Teng BQ, Zhou H, Jin JG, Grider JR, Makhlouf GM: G(i-1)/G(i-2)-dependent signaling by single-transmembrane natriuretic peptide clearance receptor. Am J Physiol Gastrointest Liver Physiol 2000;278:G974-G980.
16 Strittmatter SM, Valenzuela D, Kennedy TE, Neer EJ, Fishman MC: $G_{0}$ is a major growth cone protein subject to regulation by GAP-43. Nature 1990;344:836-841.

17 Parnell SC, Magenheimer BS, Maser RL, Rankin CA, Smine A, Okamoto T, Calvet JP: The polycystic kidney disease-1 protein, polycystin1 , binds and activates heterotrimeric G-proteins in vitro. Biochem Biophys Res Commun 1998;251:625-631

18 Smine A, Xu X, Nishiyama K, Katada T, Gambetti P, Yadav SP, Wu X, Shi YC, Yasuhara S, Homburger V, Okamoto T: Regulation of brain G-protein go by Alzheimer's disease gene presenilin-1. J Biol Chem 1998;273:1628116288.

19 Hedin KE, Duerson K, Clapham DE: Specificity of receptor-G protein interactions: Searching for the structure behind the signal. Cell Signal 1993;5:505-518.

20 Okamoto T, Nishimoto I: Detection of G protein-activator regions in M4 subtype muscarinic, cholinergic, and alpha 2-adrenergic receptors based upon characteristics in primary structure. J Biol Chem 1992;267:8342-8346.

21 Konig B, Arendt A, McDowell JH, Kahlert M, Hargrave PA, Hofmann KP: Three cytoplasmic loops of rhodopsin interact with transducin. Proc Natl Acad Sci USA 1989;86:68786882.

22 Cheung AH, Dixon RA, Hill WS, Sigal IS, Strader CD: Separation of the structural requirements for agonist-promoted activation and sequestration of the beta-adrenergic receptor. Mol Pharmacol 1990;37:775-779.

23 Chicchi GG, Graziano MP, Koch G, Hey P, Sullivan K, Vicario PP, Cascieri MA: Alterations in receptor activation and divalent cation activation of agonist binding by deletion of intracellular domains of the glucagon receptor. J Biol Chem 1997;272:7765-7769.

24 Alewijnse AE, Timmerman H, Jacobs EH, Smit MJ, Roovers E, Cotecchia S, Leurs R: The effect of mutations in the DRY motif on the constitutive activity and structural instability of the histamine $\mathrm{H}(2)$ receptor. Mol Pharmacol 2000;57:890-898.

25 Cao YJ, Gimpl G, Fahrenholz F: A mutation in the second intracellular loop of the pituitary adenylate cyclase activating polypeptide type I receptor confers constitutive receptor activation. FEBS Lett 2000;469:142-146.

26 Hwa J, Graham RM, Perez DM: Chimeras of alpha1-adrenergic receptor subtypes identify critical residues that modulate active state isomerization. J Biol Chem 1996;271:79567964.

27 Parma J, Van Sande J, Swillens S, Tonacchera M, Dumont J, Vassart G: Somatic mutations causing constitutive activity of the thyrotropin receptor are the major cause of hyperfunctioning thyroid adenomas: Identification of additional mutations activating both the cyclic adenosine 3',5'-monophosphate and inositol phosphate- $\mathrm{Ca}^{2+}$ cascades. Mol Endocrinol 1995;9:725-733.
28 Parnot C, Miserey-Lenkei S, Bardin S, Corvol $P$, Clauser E: Lessons from constitutively active mutants of $\mathrm{G}$ protein-coupled receptors. Trends Endocrinol Metab 2002;13:336.

29 Wess J, Bonner TI, Dorje F, Brann MR: Delineation of muscarinic receptor domains conferring selectivity of coupling to guanine nucleotide-binding proteins and second messengers. Mol Pharmac 1990;38:517-523.

30 Wong SK, Parker EM, Ross EM: Chimeric muscarinic cholinergic:beta-adrenergic receptors that activate Gs in response to muscarinic agonists. J Biol Chem 1990;265:6219-6224.

31 Wong SK, Ross EM: Chimeric muscarinic cholinergic:beta-adrenergic receptors that are functionally promiscuous among $\mathrm{G}$ proteins. J Biol Chem 1994;269:18968-18976.

32 Laugwitz KL, Allgeier A, Offermanns S, Spicher K, Van Sande J, Dumont JE, Schultz G: The human thyrotropin receptor: A heptahelical receptor capable of stimulating members of all four $\mathrm{G}$ protein families. Proc Natl Acad Sci USA 1996;93:116-120.

33 Hasegawa H, Negishi M, Ichikawa A: Two isoforms of the prostaglandin E receptor EP3 subtype different in agonist-independent constitutive activity. J Biol Chem 1996;271:18571860.

34 Eason MG, Liggett SB: Chimeric mutagenesis of putative G-protein coupling domains of the alpha2A-adrenergic receptor: Localization of two redundant and fully competent gi coupling domains. J Biol Chem 1996;271:1282612832.

35 Verrall S, Ishii M, Chen M, Wang L, Tram T, Coughlin SR: The thrombin receptor second cytoplasmic loop confers coupling to Gq-like G proteins in chimeric receptors: Additional evidence for a common transmembrane signaling and $\mathrm{G}$ protein coupling mechanism in $\mathrm{G}$ protein-coupled receptors. J Biol Chem 1997;272: 6898-6902.

36 Blin N, Yun J, Wess J: Mapping of single amino acid residues required for selective activation of $\mathrm{Gq} / 11$ by the $\mathrm{m} 3$ muscarinic acetylcholine receptor. J Biol Chem 1995;270:1774117748.

37 Lai FP, Mody SM, Yung LY, Kam JY, Pang CS, Pang SF, Wong YH: Molecular determinants for the differential coupling of Galpha(16) to the melatonin MT1, MT2 and Xenopus Mellc receptors. J Neurochem 2002;80: 736-745.

38 Namba T, Sugimoto Y, Negishi M, Irie A, Ushikubi F, Kakizuka A, Ito S, Ichikawa A, Narumiya S: Alternative splicing of C-terminal tail of prostaglandin E receptor subtype EP3 determines G-protein specificity. Nature 1993; 365:166-170.

39 Milligan G, Marshall F, Rees S: G16 as a universal $G$ protein adapter: Implications for agonist screening strategies. Trends Pharmacol Sci 1996; 17:235-237.

40 Jordan BA, Devi LA: G-protein-coupled receptor heterodimerization modulates receptor function. Nature 1999;399:697-700. 
41 Rocheville M, Lange DC, Kumar U, Patel SC, Patel RC, Patel YC: Receptors for dopamine and somatostatin: Formation of hetero-oligomers with enhanced functional activity. Science 2000;288:154-157.

42 Kobilka BK, Kobilka TS, Daniel K, Regan JW Caron MG, Lefkowitz RJ: Chimeric alpha 2 ,beta 2-adrenergic receptors: Delineation of domains involved in effector coupling and ligand binding specificity. Science 1988;240:1310 1316.

43 Gomeza J, Joly C, Kuhn R, Knopfel T, Bockaert J, Pin JP: The second intracellular loop of metabotropic glutamate receptor 1 cooperates with the other intracellular domains to control coupling to G-proteins. J Biol Chem 1996;271: 2199-2205.

44 Van Leeuwen DH, Eisenstein J, O'Malley K, MacKenzie RG: Characterization of a chimeric human dopamine $\mathrm{D}_{3} / \mathrm{D}_{2}$ receptor functionally coupled to adenylyl cyclase in Chinese hamster ovary cells. Mol Pharmacol 1995;48: 344-351.

45 England BP, Ackerman MS, Barrett RW: A chimeric $\mathrm{D}_{2}$ dopamine/m1 muscarinic receptor with $\mathrm{D} 2$ binding specificity mobilizes intracellular calcium in response to dopamine. FEBS Lett 1991;279:87-90.
46 Kostenis E: Is Galpha16 the optimal tool for fishing ligands of orphan G-protein-coupled receptors? Trends Pharmacol Sci 2001;22:560564.

47 Olah ME: Identification of A2a adenosine receptor domains involved in selective coupling to Gs: Analysis of chimeric A1/A2a adenosine receptors. J Biol Chem 1997;272:337-344.

48 Liggett SB, Caron MG, Lefkowitz RJ, Hnatowich $\mathrm{M}$ : Coupling of a mutated form of the human beta 2-adrenergic receptor to $\mathrm{Gi}$ and Gs: Requirement for multiple cytoplasmic domains in the coupling process. J Biol Chem 1991;266:4816-4821.

49 Cotecchia S, Ostrowski J, Kjelsberg MA, Caron MG, Lefkowitz RJ: Discrete amino acid sequences of the alpha 1-adrenergic receptor determine the selectivity of coupling to phosphatidylinositol hydrolysis. J Biol Chem 1992;267: 1633-1639.

50 Carlson SA, Chatterjee TK, Fisher RA: The third intracellular domain of the platelet-activating factor receptor is a critical determinant in receptor coupling to phosphoinositide phospholipase C-activating G proteins: Studies using intracellular domain minigenes and receptor chimeras. J Biol Chem 1996;271:2314623153.
51 Liu J, Wess J: Different single receptor domains determine the distinct $G$ protein coupling profiles of members of the vasopressin receptor family. J Biol Chem 1996;271:87728778 .

52 Spengler D, Waeber C, Pantaloni C, Holsboer F, Bockaert J, Seeburg PH, Journot L: Differential signal transduction by five splice variants of the PACAP receptor. Nature 1993;365: 170-175.

53 Gilchrist RL, Ryu KS, Ji I, Ji TH: The luteinizing hormone/chorionic gonadotropin receptor has distinct transmembrane conductors for cAMP and inositol phosphate signals. [Erratum in J Biol Chem 1996;271:26444.] J Biol Chem 1996;271:19283-19287.

54 Surprenant A, Horstman DA, Akbarali H, Limbird LE: A point mutation of the alpha 2 adrenoceptor that blocks coupling to potassium but not calcium currents. Science 1992;257: 977-980. 